\title{
Modulation of Midtropospheric $\mathrm{CO}_{2}$ by the South Atlantic Walker Circulation*
}

\author{
XUN JIANG \\ Department of Earth and Atmospheric Sciences, University of Houston, Houston, Texas \\ Edward T. Olsen, Thomas S. Pagano, AND Hui Su \\ Science Division, Jet Propulsion Laboratory, California Institute of Technology, Pasadena, California \\ YUK L. YUNG \\ Division of Geological and Planetary Sciences, California Institute of Technology, Pasadena, California
}

(Manuscript received 19 November 2014, in final form 19 February 2015)

\begin{abstract}
Midtropospheric $\mathrm{CO}_{2}$ data from the Atmospheric Infrared Sounder (AIRS) are used in this study to explore the variability of $\mathrm{CO}_{2}$ over the South Atlantic Ocean. It was found that the area-averaged $\mathrm{CO}_{2}$ over the South Atlantic Ocean is less than that over South America by about $1 \mathrm{ppm}$ during December-March. This $\mathrm{CO}_{2}$ contrast is due to the large-scale vertical circulation over this region. During December-March, there is sinking motion over the South Atlantic Ocean. The sinking motion brings high-altitude air with a slightly lower concentration of $\mathrm{CO}_{2}$ to the midtroposphere. Meanwhile, air rising over South America brings near-surface air with a higher concentration of $\mathrm{CO}_{2}$ to the midtroposphere. As a result, the AIRS midtropospheric $\mathrm{CO}_{2}$ concentration is lower over the South Atlantic Ocean than over South America during December-March. The detrended AIRS midtropospheric $\mathrm{CO}_{2}$ difference correlates well with the inverted and detrended 400-hPa vertical pressure velocity difference between the South Atlantic and South America. Results obtained from this study demonstrate the strong impact of large-scale circulation on the vertical distribution of $\mathrm{CO}_{2}$ in the free troposphere and suggest that midtropospheric $\mathrm{CO}_{2}$ measurements can be used as an innovative observational constraint on the simulation of large-scale circulations in climate models.
\end{abstract}

\section{Introduction}

Recently retrieved $\mathrm{CO}_{2}$ concentrations from satellites (Crisp et al. 2004; Miller et al. 2007; Chahine et al. 2008; Boesch et al. 2011; Crisp et al. 2012) offer a unique opportunity to explore $\mathrm{CO}_{2}$ variations in the global domain. In addition to the trend and annual cycle (Keeling et al. 1995; Pearman and Hyson 1980; Cleveland et al. 1983; Bacastow et al. 1985; Keeling et al. 1996; Buermann et al. 2007; Jiang et al. 2008; Pagano et al. 2011, 2014), $\mathrm{CO}_{2}$ concentrations also exhibit variability from intraseasonal

\footnotetext{
* Supplemental information related to this paper is available at the Journals Online website: http://dx.doi.org/10.1175/JAS-D-14-0340.s1.

Corresponding author address: Xun Jiang, Department of Earth and Atmospheric Sciences, University of Houston, 4800 Calhoun Rd., Houston, TX 77004.

E-mail: xjiang7@uh.edu
}

to interannual time scales (Bacastow 1976; Enting 1987; Feely et al. 1987; Keeling and Revelle 1985; Keeling et al. 1995; Dargaville et al. 2000; Dettinger and Ghil 1998; Keppel-Aleks et al. 2011; Jiang et al. 2012). Some recent studies further suggest that the large-scale circulations have significant influences on the temporal variability of midtropospheric $\mathrm{CO}_{2}$ ( $\mathrm{Li}$ et al. 2010; Jiang et al. 2010; Wang et al. 2011; Jiang et al. 2013a,b).

Using midtropospheric $\mathrm{CO}_{2}$ retrieval from the Atmospheric Infrared Sounder (AIRS), it was found that the Madden-Julian oscillation (MJO) could influence the midtropospheric $\mathrm{CO}_{2}$ concentrations in the tropical region ( $\mathrm{Li}$ et al. 2010). The amplitude of the MJO signal in midtropospheric $\mathrm{CO}_{2}$ is about $1 \mathrm{ppm}$ ( $\mathrm{Li}$ et al. 2010). In addition to the MJO signal, it was found that El NiñoSouthern Oscillation (ENSO) could influence the midtropospheric $\mathrm{CO}_{2}$ concentrations over the Pacific Ocean (Jiang et al. 2010, 2013a). There is more (less) midtropospheric $\mathrm{CO}_{2}$ over the central Pacific Ocean and less 
(more) midtropospheric $\mathrm{CO}_{2}$ over the western Pacific Ocean during El Niño (La Niña). In the high latitudes, the midtropospheric $\mathrm{CO}_{2}$ concentrations can be influenced by the large-scale dynamics-for example, the northern annular mode (Jiang et al. 2010) and stratospheric sudden warming (Jiang et al. 2013b). During strong (weak) polar vortex years, there is less (more) midtropospheric $\mathrm{CO}_{2}$ in the polar region (Jiang et al. 2010). It was also found that the polar midtropospheric $\mathrm{CO}_{2}$ concentrations could increase by $2-3 \mathrm{ppm}$ within a few days after the stratospheric sudden warming events (Jiang et al. 2013b). In this paper, we investigate the influence of the South Atlantic Walker circulation (Wang 2002) on the AIRS midtropospheric $\mathrm{CO}_{2}$.

\section{Data}

AIRS, version 5 (V5), midtropospheric $\mathrm{CO}_{2}$ mixing ratios retrieved by the vanishing partial derivative (VPD) method (Chahine et al. 2005; Chahine et al. 2008) were used in this study. VPD $\mathrm{CO}_{2}$ retrievals are obtained in a postprocessing stage ingesting the AIRS V5 level-2 products. The VPD algorithm applies the AIRS quality control (Susskind et al. 2011) to select retrievals and then minimizes the difference between level- 2 cloud-cleared radiances and radiances computed for the level- 2 atmospheric state. The solution is obtained when the partial derivatives of radiances in select channel sets with respect to temperature, water vapor, ozone, and $\mathrm{CO}_{2}$ are individually equal to zero (Chahine et al. 2005; Chahine et al. 2008; Olsen and Licata 2015). The same constant value of $\mathrm{CO}_{2}$ is used throughout the atmosphere across the globe as the initial guess in the original AIRS level-2 $\mathrm{CO}_{2}$ retrieval. No additional assumptions for the distribution of atmospheric $\mathrm{CO}_{2}$ are made (i.e., seasonal variations or vertical profiles from a model). The contribution function of channels employed to retrieve AIRS midtropospheric $\mathrm{CO}_{2}$, which indicates the relative fraction of the radiance observed at the top of the atmosphere arising from the various layers in the atmosphere, is maximum between 500 and $300 \mathrm{hPa}$ (Chahine et al. 2008; Olsen and Licata 2015). AIRS V5 level-3 midtropospheric $\mathrm{CO}_{2}$ retrieval products gridded at $2^{\circ} \times 2.5^{\circ}$ (latitude by longitude) from $60^{\circ} \mathrm{S}$ to $90^{\circ} \mathrm{N}$ are available from September 2002 to February 2011. Monthly mean AIRS level-3 midtropospheric $\mathrm{CO}_{2}$ are available at http://disc.sci.gsfc.nasa.gov/AIRS/ data-holdings/by-data-product-v5/AIRX3C2M (Olsen and Licata 2015). Validation by comparison to in situ aircraft measurements and retrievals by land-based upwardlooking Fourier transform interferometers demonstrated that AIRS $\mathrm{CO}_{2}$ is accurate to about 2 ppm between latitudes $40^{\circ} \mathrm{S}$ and $40^{\circ} \mathrm{N}$ (Chahine et al. 2005, 2008; Olsen and Licata 2015). The midtropospheric $\mathrm{CO}_{2}$ retrieved via the VPD method captures the correct seasonal cycle and trend compared with those from Comprehensive Observation Network for Trace Gases by Airliner (CONTRAIL) (Chahine et al. 2005).

Vertical pressure velocity data were used in this study to represent the South Atlantic Walker circulation. Vertical pressure velocity data are taken from National Centers for Environmental Prediction reanalysis 2 (NCEP2) data (Kistler et al. 2001), European Centre for MediumRange Weather Forecasts interim (ECMWF-Interim) reanalysis data (Dee et al. 2011), Modern-Era Retrospective Analysis for Research and Applications (MERRA) reanalysis data (Rienecker et al. 2011), and atmosphereocean Coupled Model Intercomparison Project phase 5 (CMIP5) (Taylor et al. 2012).

\section{Results}

To investigate the influence of the large-scale circulation on the midtropospheric $\mathrm{CO}_{2}$, we examined the AIRS midtropospheric $\mathrm{CO}_{2}$ distributions from December to March (DJFM) averaged over 2003-10 in Fig. 1. December-March was chosen because this is when the $\mathrm{CO}_{2}$ anomaly over the South Atlantic Ocean is greatest. NCEP2 400-hPa vertical pressure velocity $(d P / d t)$ calculated for the same time period was overlain on the AIRS midtropospheric $\mathrm{CO}_{2}$ in Fig. 1. There is more midtropospheric $\mathrm{CO}_{2}$ over the western Pacific Ocean and less midtropospheric $\mathrm{CO}_{2}$ over the eastern Pacific Ocean, which is related to the Walker circulation in this region as suggested by Jiang et al. (2010). Furthermore, midtropospheric $\mathrm{CO}_{2}$ concentrations are the lowest over the South Atlantic Ocean, coincident with sinking air as shown by the white solid contours in Fig. 1. Sinking air can bring lower concentrations of $\mathrm{CO}_{2}$ from high altitudes to the midtroposphere, resulting in AIRS measuring lower concentrations of midtropospheric $\mathrm{CO}_{2}$ over the South Atlantic Ocean. The rising air over South America brings high concentrations of $\mathrm{CO}_{2}$ from the surface to the midtroposphere, resulting in AIRS measuring higher concentrations of midtropospheric $\mathrm{CO}_{2}$ over South America. As shown in Fig. 1, AIRS midtropospheric $\mathrm{CO}_{2}$ concentrations over the South Atlantic Ocean are about $1 \mathrm{ppm}$ lower than that over South America from December to March. There are 3000-4000 AIRS retrievals over this region. Chahine et al. (2005) demonstrated that the distribution of individual retrieval errors exhibits Gaussian properties. Thus the error for the area-averaged $\mathrm{CO}_{2}$ is equal to $\mathrm{CO}_{2}$ standard error ( $\sim 2 \mathrm{ppm}$ ) divided by the square root of number of data. As a result, the error for the area-averaged mean $\mathrm{CO}_{2}$ is below $0.1 \mathrm{ppm}$, which is smaller than the $1-\mathrm{ppm}$ difference between the South Atlantic Ocean and South 


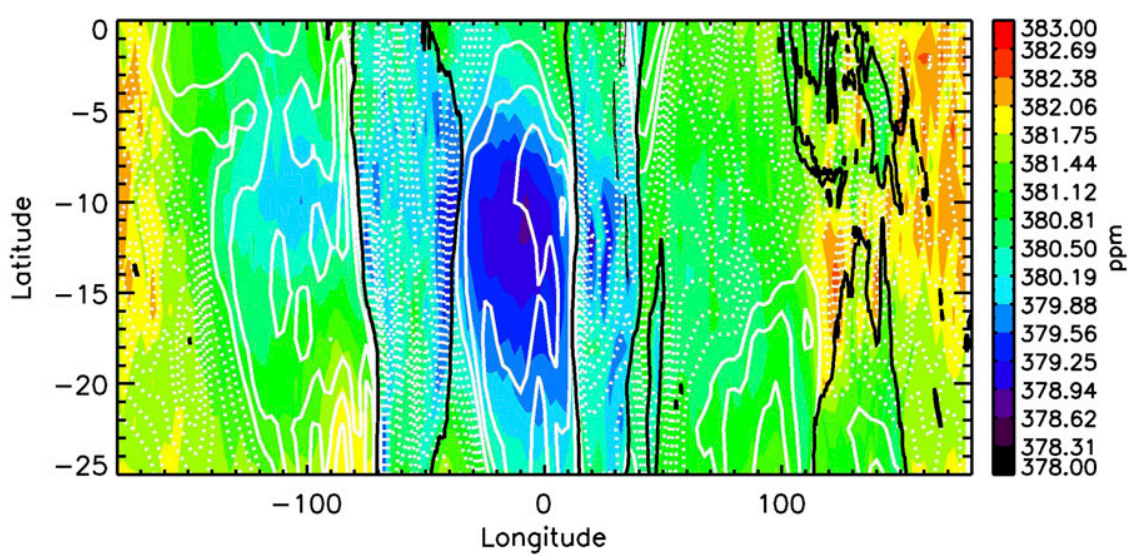

FIG. 1. AIRS midtropospheric $\mathrm{CO}_{2}(\mathrm{ppm})$ averaged from December to March during 2003-10. Color represents AIRS midtropospheric $\mathrm{CO}_{2}$. White contours are the NCEP2 $400-\mathrm{hPa} d P / d t$. Solid white contours refer to the sinking air. Dashed white contours refer to the rising air.

America. Our analysis also finds the NCEP2 400-hPa vertical pressure velocity distributions are well correlated with divergence fields at 850 and $200 \mathrm{hPa}$ (see Fig. S1 in the supplemental material), with low-level divergence (convergence) and high-level convergence (divergence) for the South Atlantic Ocean (South America).

In addition to exploring the spatial distributions of vertical pressure velocity and midtropospheric $\mathrm{CO}_{2}$, we investigated the vertical cross section of the vertical pressure velocity across $70^{\circ} \mathrm{W}-10^{\circ} \mathrm{E}$ averaged over $20^{\circ}-5^{\circ} \mathrm{S}$ from December to March during 2003-10. As shown in Fig. 2a, it is clear that air sinks over $35^{\circ} \mathrm{W}-10^{\circ} \mathrm{E}$ and rises over $70^{\circ}-35^{\circ} \mathrm{W}$. Consistent with expectations based on vertical motions, AIRS midtropospheric $\mathrm{CO}_{2}$ concentrations are relatively low over $35^{\circ} \mathrm{W}-10^{\circ} \mathrm{E}$ and relatively high over $70^{\circ}-35^{\circ} \mathrm{W}$ (Fig. 2b). The difference of midtropospheric $\mathrm{CO}_{2}$ between the South Atlantic Ocean and South America areas is about $1 \mathrm{ppm}$ from December to March.

Next, we investigated the temporal correlation between the South Atlantic Walker circulation and the midtropospheric $\mathrm{CO}_{2}$ difference between the South Atlantic Ocean $\left(20^{\circ}-5^{\circ} \mathrm{S}, 30^{\circ} \mathrm{W}-10^{\circ} \mathrm{E}\right)$ and South America $\left(20^{\circ}-5^{\circ} \mathrm{S}, 70^{\circ}-40^{\circ} \mathrm{W}\right)$. The detrended AIRS midtropospheric $\mathrm{CO}_{2}$ difference between the South Atlantic Ocean and South America is shown by the black solid line in Fig. 3a. The linear trend was calculated using the firstorder polynomial by the least squares method (Bevington and Robinson 2003) and was removed from the AIRS midtropospheric $\mathrm{CO}_{2}$ difference. To indicate the South Atlantic Walker circulation, we also calculated the detrended $400-\mathrm{hPa}$ vertical pressure velocity differences between the South Atlantic Ocean and South America from NCEP2 data (Kistler et al. 2001), ECMWF-Interim reanalysis data (Dee et al. 2011), MERRA reanalysis data (Rienecker et al. 2011), and AMIP-type CMIP5 model simulations (Taylor et al. 2012), in which observed sea surface temperature were used to drive the models. A positive (negative) value of the vertical pressure velocity difference indicates that there is more (less) sinking motion over the South Atlantic Ocean than over South America. Detrended and inverted $400-\mathrm{hPa}$ vertical pressure velocity differences from reanalysis data and different models are shown in Fig. 3a by the various color dashed lines. $\mathrm{CO}_{2}$ and vertical pressure velocity differences from 2003 to 2008 are shown, since most model simulations ended in 2008.

As shown in Fig. 3a, the $\mathrm{CO}_{2}$ difference (South Atlantic Ocean minus South America) is related to the vertical pressure velocity difference and there is a reoccurring seasonal variation. The $\mathrm{CO}_{2}$ difference is negative (positive) when the vertical pressure velocity difference is positive (negative). It suggests that the concentration of midtropospheric $\mathrm{CO}_{2}$ over the South Atlantic Ocean compared to that over South America is impacted by the vertical transport due to the South Atlantic Walker circulation. The relative concentration of midtropospheric $\mathrm{CO}_{2}$ over the South Atlantic is diminished by sinking air and enhanced by rising air. Air converges at the surface and diverges in the upper levels over South America in DJFM (see Fig. S1 in the supplemental material), leading to rising air over South America, which in turn can bring high concentrations of $\mathrm{CO}_{2}$ from the surface to the midtroposphere. Meanwhile, air diverges at the surface and converges in the upper levels over South Atlantic Ocean in DJFM, leading to sinking air over the South Atlantic Ocean, which in turn can bring low concentrations $\mathrm{CO}_{2}$ from high altitudes to the midtroposphere. $\mathrm{CO}_{2}$ difference 


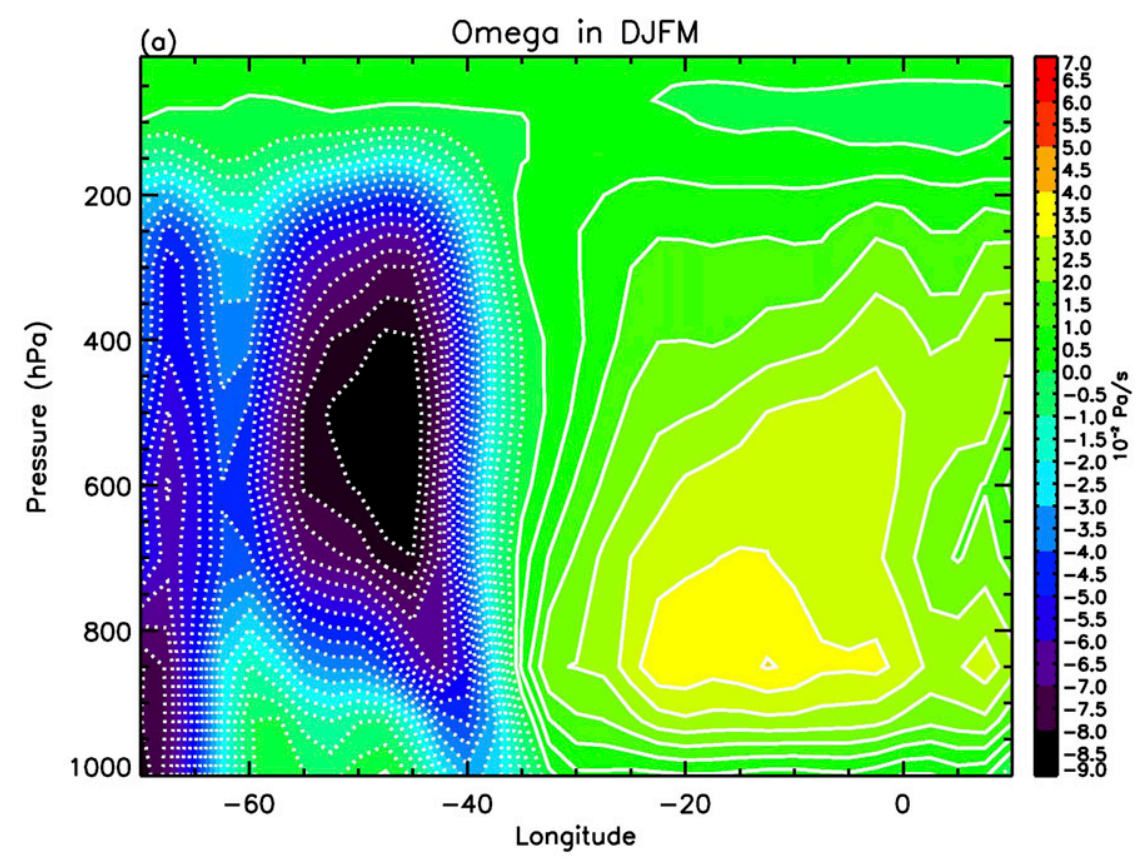

(b)

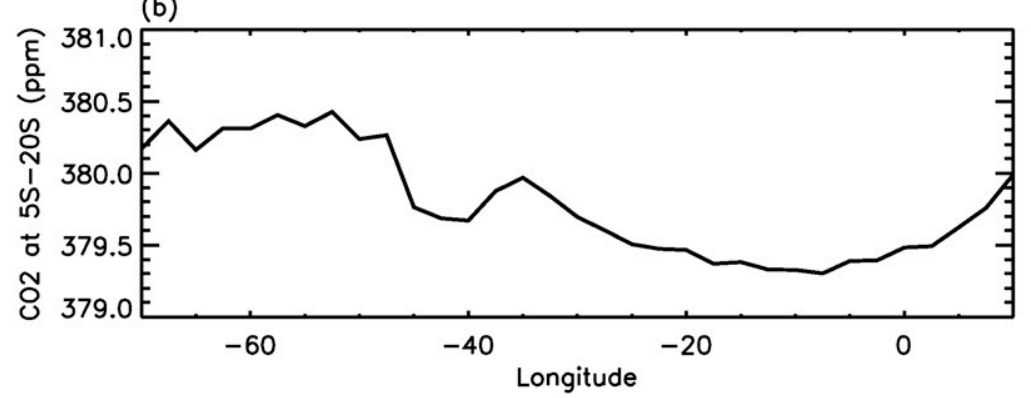

FIG. 2. (a) Vertical pressure velocity $\left(10^{-2} \mathrm{~Pa} \mathrm{~s}^{-1}\right)$ averaged over $20^{\circ}-5^{\circ} \mathrm{S}$ from December to March during 2003-10. Solid white contours refer to the sinking air. Dashed white contours refer to the rising air. (b) AIRS $\mathrm{CO}_{2}$ (ppm) averaged over $20^{\circ}-5^{\circ} \mathrm{S}$ from December to March during 2003-10.

amplitudes are smaller in 2007 and 2008 than in earlier years, which might be related to $\mathrm{CO}_{2}$ surface-emission contrasts between South America and the South Atlantic Ocean. The interannual variability of the $\mathrm{CO}_{2}$ difference amplitudes will be explored in the future when $\mathrm{CO}_{2}$ surface emission data are available.

As shown in Fig. 3a, the detrended AIRS $\mathrm{CO}_{2}$ difference correlates well with the inverted and detrended vertical pressure velocity differences. The correlation coefficient between the detrended AIRS $\mathrm{CO}_{2}$ difference (black solid line) and the inverted and detrended mean vertical pressure velocity difference (red dashed line) is 0.66 . The corresponding significance level is $2 \%$. The significance statistics for the correlation were generated by a Monte Carlo method (Press et al. 1992; Jiang et al. 2004). The correlation coefficients between the detrended AIRS $\mathrm{CO}_{2}$ difference and the inverted and detrended vertical pressure velocity differences derived from reanalysis datasets and CMIP5 model simulations range between 0.55 and 0.72 (Fig. 3b). The correlation coefficients are 0.67 for NCEP2, 0.64 for ERA-Interim, 0.55 for MERRA, and between 0.57 and 0.72 for CMIP5 simulations. Given the importance of large-scale circulation in driving global energy and water cycles, improving model simulations of large-scale circulation is critical to reducing the model spread in climate sensitivity estimates (Su et al. 2014). Since there are limited direct observations of vertical velocity, the midtropospheric $\mathrm{CO}_{2}$ can be utilized as an indirect constraint on model representation of large-scale circulation-for example, the vertical velocity of the South Atlantic Walker cell.

\section{Conclusions}

AIRS midtropospheric $\mathrm{CO}_{2}$ data were used in this study to investigate the impact of large-scale circulation 

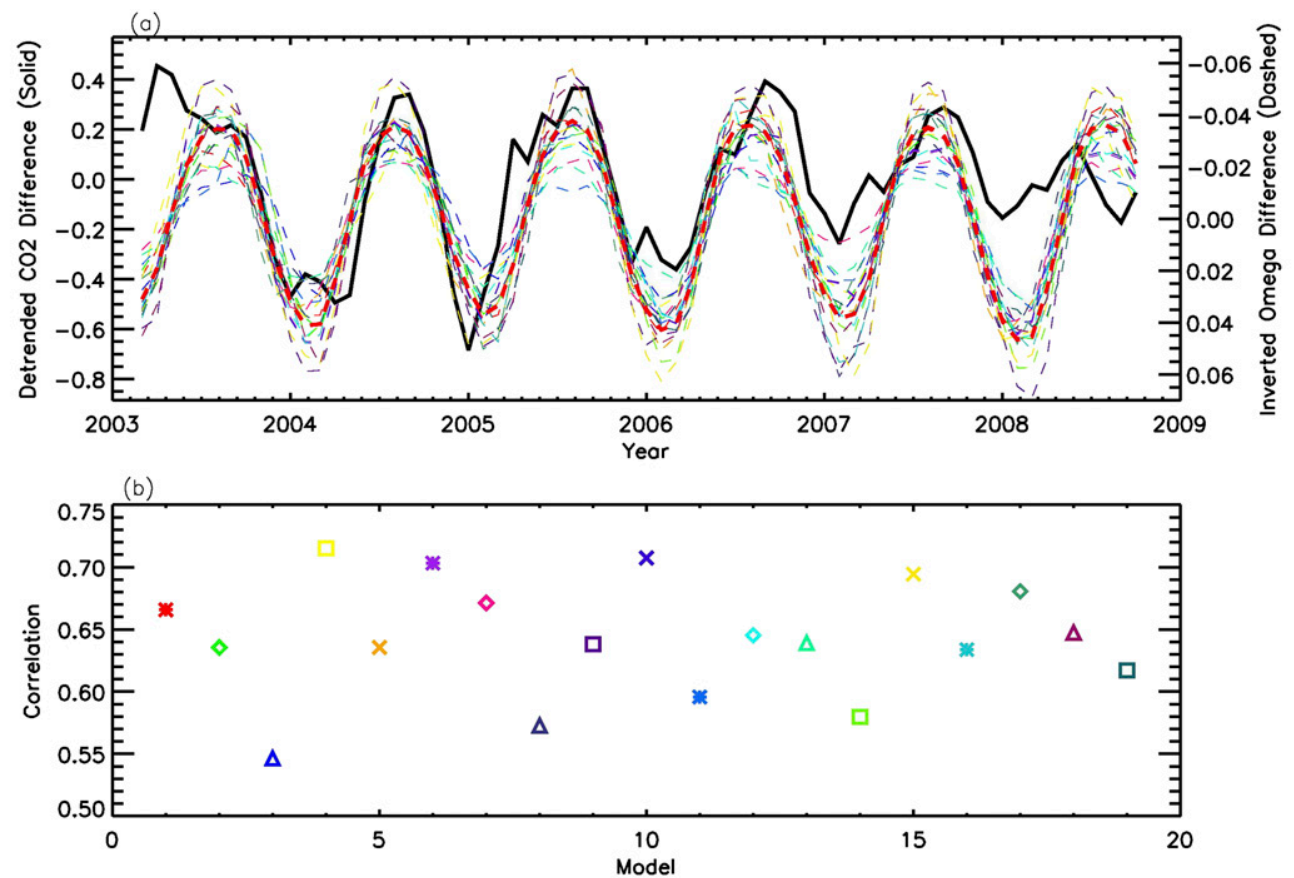

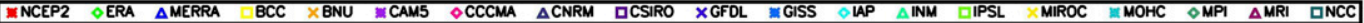

FIG. 3. (a) Difference of the detrended AIRS midtropospheric $\mathrm{CO}_{2}$ between the South Atlantic Ocean $\left(20^{\circ}-5^{\circ} \mathrm{S}\right.$, $\left.30^{\circ} \mathrm{W}-10^{\circ} \mathrm{E}\right)$ and South America $\left(20^{\circ}-5^{\circ} \mathrm{S}, 70^{\circ}-40^{\circ} \mathrm{W}\right)$ (black solid line) and difference of the inverted and detrended $400-\mathrm{hPa} d P / d t$ between the South Atlantic Ocean and South America from reanalysis data and various CMIP5 models (thin dashed lines). Thick red dashed line is the averaged $d P / d t$ difference from all reanalysis data and model simulations. (b) Correlation coefficients between detrended $\mathrm{CO}_{2}$ difference and detrended and inverted $d P / d t$ differences from reanalysis data and CMIP5 models. A 3-month running mean has been applied to all time series to remove the high-frequency signals.

on midtropospheric $\mathrm{CO}_{2}$ concentrations over the South Atlantic Ocean for the first time. It is found that concentrations of midtropospheric $\mathrm{CO}_{2}$ over the South Atlantic Ocean are lower than over the surrounding region during December-March. As illustrated in Fig. 4, the sinking air over the South Atlantic Ocean brings lower- $\mathrm{CO}_{2}$-concentration air from higher altitudes to the midtroposphere. Meanwhile, the rising air over South America brings near-surface air containing higher concentrations of $\mathrm{CO}_{2}$ to the midtroposphere during December-March. As a response to the vertical motions, the AIRS retrieved midtropospheric $\mathrm{CO}_{2}$ concentrations are about $1 \mathrm{ppm}$ lower over the South Atlantic Ocean than over South America. We also find that the detrended AIRS midtropospheric $\mathrm{CO}_{2}$ difference (South Atlantic Ocean minus South America) correlates well with the South Atlantic Walker circulation indicated by the inverted and detrended vertical pressure velocity differences from three reanalysis data and CMIP5 simulations. The vertical pressure velocity associated with the South Atlantic Walker circulation can lead to a difference as great as $1 \mathrm{ppm}$ in the midtropospheric $\mathrm{CO}_{2}$. While all reanalysis datasets and CMIP5 simulations show a statistically significant correlation between the midtropospheric $\mathrm{CO}_{2}$ difference and the South Atlantic Walker cell, the correlation coefficients range between 0.55 and 0.72 . We conclude that

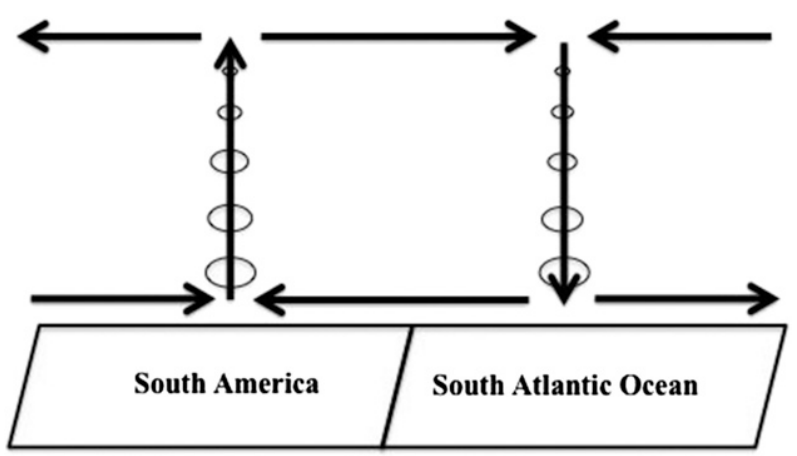

FIG. 4. Diagram to illustrate the influence of South Atlantic Walker circulation on the midtropospheric $\mathrm{CO}_{2}$ concentrations. Air movements are highlighted by the arrows. Ovals represent the $\mathrm{CO}_{2}$ concentrations, which are high near the surface and low in the high altitudes. 
the clear modulation of large-scale circulation on the midtropospheric $\mathrm{CO}_{2}$ enables an innovative observational constraint on the model representation of large-scale circulation (i.e., through the use of AIRS midtropospheric $\mathrm{CO}_{2}$ measurements). Chemical transport models and $\mathrm{CO}_{2}$ flux inversion projects are highly dependent on the accurate simulations of large-scale circulation to identify the impact of surface emissions on tracer distributions and evolutions. $\mathrm{CO}_{2}$ measurements from AIRS and the newly available Orbiting Carbon Observatory 2 $(O C O-2)$ would likely enable a leap of progress in climate model improvements.

Acknowledgments. We thank two anonymous reviewers for helpful comments. XJ and YLY were supported by the AIRS project, $O C O-2$ project, and NASA Grant NNX13AC04G to UH and Caltech. Part of this research was carried out at the Jet Propulsion Laboratory, California Institute of Technology, under a contract with the National Aeronautics and Space Administration.

\section{REFERENCES}

Bacastow, R. B., 1976: Modulation of atmospheric carbon dioxide by the Southern Oscillation. Nature, 261,116-118, doi:10.1038/ $261116 \mathrm{a} 0$.

— C. D. Keeling, and T. P. Whorf, 1985: Seasonal amplitude increase in atmospheric $\mathrm{CO}_{2}$ concentration at Mauna Loa, Hawaii, 1959-1982. J. Geophys. Res., 90, 10 529-10 540, doi:10.1029/ JD090iD06p10529.

Bevington, P. R., and D. K. Robinson, 2003: Data Reduction and Error Analysis for the Physical Science. 3rd ed. McGraw-Hill, 336 pp.

Boesch, H., D. Baker, B. Connor, D. Crisp, and C. Miller, 2011: Global characterization of $\mathrm{CO}_{2}$ column retrievals from shortwave-infrared satellite observations of the Orbiting Carbon Observatory-2 Mission. Remote Sens., 3, 270-304, doi:10.3390/ rs3020270.

Buermann, W., B. Lintner, C. Koven, A. Angert, J. E. Pinzon, C. J. Tucker, and I. Fung, 2007: The changing carbon cycle at the Mauna Loa Observatory. Proc. Natl. Acad. Sci. USA, 104, 4249-4254, doi:10.1073/pnas.0611224104.

Chahine, M., C. Barnet, E. T. Olsen, L. Chen, and E. Maddy, 2005: On the determination of atmospheric minor gases by the method of vanishing partial derivatives with application to $\mathrm{CO}_{2}$. Geophys. Res. Lett., 32, L22803, doi:10.1029/2005GL024165.

_ , and Coauthors, 2008: Satellite remote sounding of midtropospheric $\mathrm{CO}_{2}$. Geophys. Res. Lett., 35, L17807, doi:10.1029/ 2008GL035022.

Cleveland, M. S., A. E. Freeny, and T. E. Graedel, 1983: The seasonal component of atmospheric $\mathrm{CO}_{2}$ Information from new approaches to the decomposition of seasonal time series. J. Geophys. Res., 88, 10 934-10 946, doi:10.1029/JC088iC15p10934.

Crisp, D., and Coauthors, 2004: The Orbiting Carbon Observatory (OCO) mission. Adv. Space Res., 34, 700-709, doi:10.1016/ j.asr.2003.08.062.

- , and Coauthors, 2012: The ACOS $\mathrm{CO}_{2}$ retrieval algorithmPart II: Global $\mathrm{X}_{\mathrm{CO} 2}$ data characterization. Atmos. Meas. Tech., 5, 687-707, doi:10.5194/amt-5-687-2012.
Dargaville, R. J., R. M. Law, and F. Pribac, 2000: Implications of interannual variability in atmospheric circulation on modeled $\mathrm{CO}_{2}$ concentrations and source estimates. Global Biogeochem. Cycles, 14, 931-943, doi:10.1029/1999GB001166.

Dee, D. P., and Coauthors, 2011: The ERA-Interim reanalysis: Configuration and performance of the data assimilation system. Quart J. Roy. Meteor. Soc., 137, 553-597, doi:10.1002/qj.828.

Dettinger, M. D., and M. Ghil, 1998: Seasonal and interannual variations of atmospheric $\mathrm{CO}_{2}$ and climate. Tellus, 50B, 1-24, doi:10.1034/j.1600-0889.1998.00001.x.

Enting, I. G., 1987: The interannual variation in the seasonal cycle of carbon dioxide concentration at Mauna Loa. J. Geophys. Res., 92, 5497-5504, doi:10.1029/JD092iD05p05497.

Feely, R. A., R. H. Gammon, B. A. Taft, P. E. Pullen, L. S. Waterman, T. J. Conway, J. F. Gendron, and D. P. Wisegarver, 1987: Distribution of chemical tracers in the eastern equatorial Pacific during and after the 1982/1983 ENSO event. J. Geophys. Res., 92, 6545-6558, doi:10.1029/JC092iC06p06545.

Jiang, X., C. D. Camp, R. Shia, D. Noone, C. Walker, and Y. Yung, 2004: Quasi-biennial oscillation and quasi-biennial oscillationannual beat in the tropical total column ozone: A twodimensional model simulation. J. Geophys. Res., 109, D16305, doi:10.1029/2003JD004377.

, Q. Li, M. Liang, R. Shia, M. T. Chahine, E. T. Olsen, L. Chen, and Y. L. Yung, 2008: Simulation of upper tropospheric $\mathrm{CO}_{2}$ from chemistry and transport models. Global Biogeochem. Cycles, 22, GB4025, doi:10.1029/2007GB003049.

—, M. T. Chahine, E. T. Olsen, L. L. Chen, and Y. L. Yung, 2010: Interannual variability of mid-tropospheric $\mathrm{CO}_{2}$ from Atmospheric Infrared Sounder. Geophys. Res. Lett., 37, L13801, doi:10.1029/2010GL042823.

,,-- Q. Li, M. Liang, E. T. Olsen, L. Chen, J. Wang, and Y. L. Yung, 2012: $\mathrm{CO}_{2}$ semiannual oscillation in the middle troposphere and at the surface. Global Biogeochem. Cycles, 26, doi:10.1029/2011GB004118.

— J. Wang, E. T. Olsen, M. Liang, T. S. Pagano, L. Chen, S. J. Licata, and Y. L. Yung, 2013a: Influence of El Niño on midtropospheric $\mathrm{CO}_{2}$ from Atmospheric Infrared Sounder and Model. J. Atmos. Sci., 70, 223-230, doi:10.1175/JAS-D-11-0282.1.

, T. S. Pagano, L. Chen, and Y. L. Yung, 2013b: Influence of stratospheric sudden warming on AIRS midtropospheric $\mathrm{CO}_{2}$. J. Atmos. Sci., 70, 2566-2573, doi:10.1175/ JAS-D-13-064.1.

Keeling, C. D., and R. Revelle, 1985: Effects of El Nino/Southern Oscillation on the atmospheric content of carbon dioxide. Meteoritics, 20, 437-450.

- , T. P. Whorf, M. Wahlen, and J. Vanderplicht, 1995: Interannual extremes in the rate of rise of atmospheric carbon dioxide since 1980. Nature, 375, 666-670, doi:10.1038/375666a0.

_ J. F. S. Chin, and T. P. Whorf, 1996: Increased activity of northern vegetation inferred from atmospheric $\mathrm{CO}_{2}$ measurements. Nature, 382, 146-149, doi:10.1038/382146a0.

Keppel-Aleks, G., P. O. Wennberg, and T. Schneider, 2011: Sources of variations in total column carbon dioxide. Atmos. Chem. Phys., 11, 3581-3593, doi:10.5194/acp-11-3581-2011.

Kistler, R., and Coauthors, 2001: The NCEP-NCAR 50-Year Reanalysis: Monthly means CD-ROM and documentation. Bull. Amer. Meteor. Soc., 82, 247-267, doi:10.1175/ 1520-0477(2001)082<0247:TNNYRM $>2.3$.CO;2.

Li, K. F., B. Tian, D. E. Waliser, and Y. L. Yung, 2010: Tropical mid-tropospheric $\mathrm{CO}_{2}$ variability driven by the Madden-Julian oscillation. Proc. Natl. Acad. Sci. USA, 107, 19171-19175, doi:10.1073/pnas.1008222107. 
Miller, C. E., and Coauthors, 2007: Precision requirements for spacebased $\mathrm{X}_{\mathrm{CO} 2}$ data. J. Geophys. Res., 112, D10314, doi:10.1029/ 2006JD007659.

Olsen, E. T., and S. J. Licata, 2015: AIRS Version 5 release tropospheric $\mathrm{CO}_{2}$ products. Jet Propulsion Laboratory, 38 pp. [Available online at http://disc.sci.gsfc.nasa.gov/AIRS/documentation/v5_docs/ AIRS_V5_Release_User_Docs/AIRS-V5-Tropospheric-CO2Products.pdf.]

Pagano, T. S., E. T. Olsen, M. T. Chahine, A. Ruzmainkin, H. Nguyen, and X. Jiang, 2011: Monthly representations of mid-tropospheric carbon dioxide from the Atmospheric Infrared Sounder. Imaging Spectrometry XVI, S. Shaklan, Ed., International Society for Optical Engineering (SPIE Proceedings, Vol. 8158), 81580C, doi:10.1117/12.894960.

,$- \ldots$, H. Nguyen, A. Ruzmaikin, X. Jiang, and L. Perkins, 2014: Global variability of midtropospheric carbon dioxide as measured by the Atmospheric Infrared Sounder. J. Appl. Remote Sens., 8, 084984, doi:10.1117/1.JRS.8.084984.

Pearman, G. I., and P. Hyson, 1980: Activities of the global biosphere as reflected in atmospheric $\mathrm{CO}_{2}$ records. J. Geophys. Res., 85, 4457-4467, doi:10.1029/JC085iC08p04457.

Press, W., S. Teukolsky, W. Vetterling, and B. Flannery, 1992: Numerical Recipes in Fortran 77: The Art of Scientific Computing. 2nd ed. Cambridge University Press, 933 pp.
Rienecker, M. M., and Coauthors, 2011: MERRA: NASA's Modern-Era Retrospective Analysis for Research and Applications. J. Climate, 24, 3624-3648, doi:10.1175/ JCLI-D-11-00015.1.

Su, H., J. H. Jiang, C. Zhai, T. J. Shen, J. D. Neelin, G. L. Stephens, and Y. L. Yung, 2014: Weakening and strengthening structures in the Hadley circulation change under global warming and implications for cloud response and climate sensitivity. J. Geophys. Res. Atmos., 119, 5787-5805, doi:10.1002/ 2014JD021642.

Susskind, J., J. Blaisdell, L. Iredell, and F. Keita, 2011: Improved temperature sounding and quality control methodology using AIRS/AMSU data: The AIRS Science Team Version 5 retrieval algorithm. IEEE Trans. Geosci. Remote Sens., 49, 883907, doi:10.1109/TGRS.2010.2070508.

Taylor, K. E., R. J. Stouffer, and G. A. Meehl, 2012: An overview of CMIP5 and the experiment design. Bull. Amer. Meteor. Soc., 93, 485-498, doi:10.1175/BAMS-D-11-00094.1.

Wang, C., 2002: Atlantic climate variability and its associated atmospheric circulation cells. J. Climate, 15, 1516-1536, doi:10.1175/ 1520-0442(2002)015<1516:ACVAIA > 2.0.CO;2.

Wang, J., and Coauthors, 2011: The influence of tropospheric biennial oscillation in mid-tropospheric $\mathrm{CO}_{2}$. Geophys. Res. Lett., 38, L20805, doi:10.1029/2011GL049288. 